\title{
Relationship between the Cleanliness of Nails and the Usage of Footwear with the Incidence of Helminths Infections on Elementary Student in Sibolga of 2019
}

\author{
$\underline{\text { Roslina Pane }^{1}, \text { Nurmaini }^{2}, \text { Lita Sri Andayani }}{ }^{3}$ \\ 1,2,3 Department of Public Health Promotion, Faculty of Public Health, Universitas Sumatera Utara, \\ Indonesia \\ Email: roslinapane65@gmail.com
}

\begin{abstract}
:
Soil - Transmitted Helminths (STH) infection is one of the most common infections in the world, especially for the poor society. Worm infections spread through eggs in human feces that contaminate soils where the level of sanitation is bad. Worm infections are widespread in tropical and subtropical regions, one of which is Indonesia. Around 568 million school-age children have high potential for STH because they live in an areas prone to STH infections (WHO, 2017a). Soil Transmitted Helminths Infection is a health problem with a high prevalence in the tropics and subtropics, especially Indonesia. Children with the primary school age are the group that most often suffer from infection because more daily activities are in contact with the soil and in clean living behavior is still low. The purpose of this study is to find out the relationship between sex and Helminths Infection, nail hygiene and using footwear with the incidence of helminthiasis in students in the city of Sibolga. The results obtained from this study are the number of students infected by helminthiasis by $33.82 \%$, based on male gender as many as 20 students $(60.6 \%)$ of the 44 students examined and the number of infected women as many as 18 students (39.4\%) of 41 female students examined. The results of the category assessment, for the category of nail hygiene with a good 32.94 percent (28 students) and the category is less good at 67.06 percent (57 people). From the bivariate analysis there was no relationship between sex and helminthiasis. The results of nail hygiene analysis, there is a significant relationship between nail hygiene with helminthiasis infection with a value of $p=0.009$ and the value of the prevalence ratio of 2.751. Analysis using footwear, there is a significant relationship between the habit of using footwear with helminthiasis infection with a value of $p=0.004$ with a prevalence ratio value of 3.195. From the results of the multiple logistic regression test, the most influential value between nail hygiene and using footwear is using footwear with a $p$ value $=0.009$ with a constant value of 3.410 .
\end{abstract}

Keywords:

succession planning; competency; organizational culture; adjusting (variable); infrastructural

\section{Introduction}

Worm infection is an infectious disease caused by the environment and is still a problem for Indonesia's health (Rahmat, 2005), which is called Soil Transmitted Helminths (STH) or intestinal worms that infect humans, which are transmitted through soil (CDC, 2011) that has been contaminated by faeces containing worm eggs in areas of poor sanitation (WHO, 2019). Those included from STH include Ascaris lumbricoides, Ancylostoma duodenale, Necator americanus, Trichuris trichiura, and Stercoralis strongyloides (Bethony et al., 2006).

Worm infections include neglected disease, which is an infectious disease that does not get much attention and is a chronic disease that does not show clear clinical symptoms and the effects caused. Because it will look the effects caused after a long term such as malnutrition, developmental disorders, cognitive disorders in children (Ministry of Health Republic of Indonesia, 2017, Kurniawan, 2010) delayed growth, intellectual delay and inability to attend 
education (Bethony et al., 2006) and can also increase susceptibility to malaria, tuberculosis, diarrhea and anemia (Adam et al., 2005). Thus affecting the quality of Indonesian human resources.

In theory, the incidence of helminthiasis is influenced by environmental factors and personal hygiene, namely the habit of children washing their hands before eating, the frequency of cutting nails, habit of playing ground that has been contaminated with worm eggs, possession of latrines, the floor of the house and the availability of clean water (Endriani et al, 2011). Transmission of helminthiasis is very rapid, this development is due to the development phase into infective larvae which only takes 24-36 hours and worm eggs can survive for several years (Supali, 2008).

Sibolga City is a tropical area with a maximum temperature of around $31.65^{\circ} \mathrm{C}$ with a total rainfall of 267 days, and an average humidity of 82.6796 and an average wind speed of $6.16 \mathrm{~m} /$ sec. Sibolga city is one of the areas with the highest population density in northern Sumatra, with a population density of 8,139 people $/ \mathrm{km}^{2}$.

\section{Research Methods}

This research is a descriptive analytic study with cross sectional approach, namely by collecting data at once at a time. From January to August 2019. To find out the number of helminthiasis infection through feces examination. To find out the behavior of nail polish and using footwear, questionnaire filling was done. After collecting the stool, a questionnaire was then given.

Research subject. The study population was all students enrolled in Mis-Nurulfalah, MisAlmuklhisin, Muhammadiyah 3, while the sample was students in grades IV and V. With a total sample of 85 respondents.

\subsection{Filling out the questionnaire}

Blank questionnaires were distributed to all students who were research samples and filled out together in each class. The questionnaire contained personal data, behavioral habits of washing hands, before eating and after defecation (bowel movements), habits of cutting nails and using footwear during recess and when leaving the house, playing habits on the ground and habit of nail biting when playing. After the questionnaire is filled out completely, the questionnaire is collected to the researcher.

\subsection{Stool collection}

At the beginning of the study after coordinating with the school and UKS teachers, each research subject was given an empty container that had been given a label (name and class). The researcher informed the method of collecting faeces into the container. Then the stool is collected the next day and to determine whether the stool is the stool from the student.

Identification of worm eggs. Worm egg identification was carried out by the Kato Katz method in the 2017 Permenkes in the UPTD laboratory of the Sibolga City Health Office. In addition to the identification of worm eggs, eggs are counted to calculate the intensity of worm infections according to Kobayasih in Garcia LS. 


\section{Discussion}

\subsection{Results}

Table 1. Frequency distribution of respondent characteristics

\begin{tabular}{lcc} 
Characteristics of Respondents & $\mathrm{n}$ & $\mathbf{\%}$ \\
\hline Schools & 46 & 54,1 \\
Mis-Almuklhisin & 23 & 27,1 \\
Mis-Nurul Falah & 16 & 18,8 \\
Muhammadiyah - 3 & & 51,8 \\
Gender of Respondents & 44 & 48,2 \\
Male & 41 & \\
Female & & 45,5 \\
Checkup result & 20 & 31,7 \\
Male & 13 & \\
Female &
\end{tabular}

Source: Primary Data (2019)

From 85 respondents in this study we can see the number of respondents with female gender as many as 41 students $(48.2 \%)$ and men as many as 44 students $(51.8 \%)$.

Table 2. Sex frequency distribution with helminthiasis

\begin{tabular}{|l|l|c|c|c|c|}
\hline \multirow{2}{*}{ No } & \multirow{2}{*}{ Gender } & \multicolumn{2}{|c|}{ Results } & \multicolumn{2}{c|}{ Total } \\
\cline { 3 - 6 } & & Positive & Negative & $\mathrm{n}$ & $\%$ \\
\hline 1 & Male & 20 & 24 & 44 & $51,8 \%$ \\
\hline 2 & Female & 13 & 28 & 41 & $48,2 \%$ \\
\hline \multicolumn{2}{|c|}{ Total } & 33 & 52 & 85 & 100 \\
\hline
\end{tabular}

Source: Rimer data (2019)

Of the 44 male respondents found that infected with worms as many as 20 people (45.45\%), and from 41 female sex there are 13 people $(46.42 \%)$.

Table 3. Distribution of helminthiasis based on school origin

\begin{tabular}{lccccc}
\hline \multirow{2}{*}{ Helminthiasis } & $\begin{array}{c}\text { Mis- } \\
\text { Almuklhisin }\end{array}$ & $\begin{array}{c}\text { Mis- } \\
\text { Nurulfalah }\end{array}$ & $\begin{array}{c}\text { Muhammadiyah } \\
-3\end{array}$ & Total \\
\cline { 2 - 6 } & $\mathrm{n}$ & $\mathrm{n}$ & $\mathrm{n}$ & $\mathrm{n}$ & $\%$ \\
\hline Positive (+) & 17 & 9 & 7 & 33 & 38,82 \\
Negative (-) & 29 & 14 & 9 & 52 & 61,18 \\
\hline
\end{tabular}

Source: 2019 prime data

From the table above we can see the percentage of respondents infected with helminthiasis based on school origin, from 46 Mis-Almuklisin students there were 17 infected students, 33 students from Mis-Nurul Falah there were 9 students infected with helminthiasis and 16 students from Muh-3 there were 7 students infected with worms.

Table 4. Personal categories of nail hygiene hygiene

\begin{tabular}{lcc}
\hline Personal hygiene category of nail hygiene & n & \% \\
\hline Not good & 57 & 67,06 \\
Good & 28 & 32,94 \\
\hline Total & 85 & 100 \\
\hline
\end{tabular}


Source: Primary Data (2019)

Based on the table above we can see the category of personal hygiene nail hygiene with a less good category of 57 respondents $(67.06 \%)$, and a good category of 28 respondents $(32.94 \%)$.

Table 5. Personal hygiene using footwear

\begin{tabular}{lcc}
\hline Personal hygiene category uses footwear & n & \% \\
\hline Not good & 59 & 69,41 \\
Good & 26 & 30,59 \\
\hline Total & 85 & 100 \\
\hline
\end{tabular}

Source: Primary Data (2019)

Based on the table above we can see the personal hygiene category using footwear with the category of less than 59 respondents $(69.41 \%)$ and the good category of 26 respondents $(30.59 \%)$

\section{Bivariate Analysis}

Table 6. Relationship between sex and helminthiasis

\begin{tabular}{|c|c|c|c|c|c|c|c|}
\hline \multirow{3}{*}{ Use footwear } & \multicolumn{4}{|c|}{ Total } & \multirow{3}{*}{ Total } & \multirow{3}{*}{ Score of $\mathrm{p}$} & \multirow{3}{*}{ PR } \\
\hline & \multicolumn{2}{|c|}{ Positive } & \multicolumn{2}{|c|}{ Negative } & & & \\
\hline & $\mathrm{n}$ & $\%$ & $\mathrm{n}$ & $\%$ & & & \\
\hline Male & 20 & 60,6 & 24 & 46,2 & 44 & & \\
\hline Female & 13 & 39,4 & 28 & 53,8 & 41 & & \\
\hline
\end{tabular}

Source: Primary Data (2019)

Based on the analysis of the relationship between sex and helminthiasis we can see, there was no significant relationship found between sex with helminthiasis with a p-value of 0.266 and the prevalence of helminthiasis was 1.434 .

Table 7. Relationship of nail hygiene with helminthiasis infection

\begin{tabular}{|c|c|c|c|c|c|c|c|}
\hline \multirow{3}{*}{ Nail cleanliness } & \multicolumn{4}{|c|}{ Helminthiasis } & \multirow{3}{*}{ Total } & \multirow{3}{*}{ Score of $p$} & \multirow{3}{*}{ PR } \\
\hline & \multicolumn{2}{|c|}{ Positive } & \multicolumn{2}{|c|}{ Negative } & & & \\
\hline & $\mathrm{n}$ & $\%$ & $\mathrm{n}$ & $\%$ & & & \\
\hline Not good & 28 & 84,4 & 29 & 55,8 & 57 & & \\
\hline Good & 5 & 15,2 & 23 & 44,2 & 28 & & \\
\hline
\end{tabular}

Source: Primary Data (2019)

Based on the analysis of the relationship of nail hygiene with sex, from the results of the analysis we can see that found a significant relationship between nail hygiene and helminthiasis infection with a p-value of 0.009 and worm prevalence of 2.751 .

Table 8. Relationships using footwear with helminthiasis

\begin{tabular}{cccc}
\multirow{2}{*}{ Use footwear } & \multicolumn{3}{c}{ Helminthiasis } \\
\cline { 2 - 3 } Total Score of $\mathrm{p}$ & \multicolumn{2}{c}{ Pogative } \\
\cline { 2 - 3 } & $\mathrm{n}$ & $\mathrm{n}$ & $\%$
\end{tabular}




\begin{tabular}{|c|c|c|c|c|c|c|c|}
\hline Not good & 29 & 87,9 & 30 & 57,7 & 59 & \multirow{2}{*}{0,004} & \multirow{2}{*}{3,195} \\
\hline Good & 4 & 12,1 & 22 & 42,3 & 26 & & \\
\hline
\end{tabular}

Source: Primary Data (2019)

Based on the analysis of the relationship using footwear with helminthiasis there was a significant relationship between personal hygiene using footwear with helminthiasis infection with a value of $\mathrm{p}=0.004$ and the prevalence ratio to helminthiasis was 3,195.

Table 9. List of multivariate logistic regression logistic tabulation tables

\begin{tabular}{llllll}
\hline \multirow{2}{*}{ Variable } & \multirow{2}{*}{ B } & \multirow{2}{*}{$\mathbf{P ( S i g )}$} & \multirow{2}{*}{ Exp (B) } & \multicolumn{2}{c}{$\mathbf{9 5 \%}$} \\
\cline { 5 - 7 } & & & & Lower & Upper \\
\hline Nail cleanliness & $-1,436$ & 0,013 &, 238 & 0,076 & 0,734 \\
Use footwear & $-1,618$ & 0,009 &, 198 & 0,059 & 0,669 \\
Constant & 3,410 & 0,002 & & & \\
\hline
\end{tabular}

Source: Primary Data (2019)

Based on the analysis of the relationship of personal hygiene using footwear, from the results of the analysis above we can see that found a significant relationship of personal hygiene using footwear with helminthiasis with a p-value of 0.004 and worm prevalence value of 3.195 . Based on the results of the multiple logistic regression tests above, a regression equation model can be made to see the probability of nail hygiene and use footwear as follows:

$$
\begin{gathered}
P x=\frac{1}{1+e^{-(\alpha+\beta x 1+\beta 2 \times 2)}} \\
P x=\frac{1}{1+3,410^{-1,486-1,618}} \\
P x=\frac{1}{1+2,718^{0,856}} \\
P x=\frac{1}{1,96708} \\
P x=0,50=50 \%
\end{gathered}
$$

\subsection{Discussion}

Worm examination results found the percentage of helminthiasis infections in respondents amounted to $33.82 \%$, where this figure is still high. The prevalence of national worm infection is expected to be $20 \%$. High prevalence of helminthiasis also occurred in China in the Guizhou area by $40.1 \%$ (Xiaobing, 2012)

Based on the results of bivariate analysis of sex with helminthiasis it was found that there was no influence of sex with helminthiasis, where no significant differences were found between the sexes of helminthiasis infection. In contrast to the research conducted by Samuel (2017) where the female sex is more dominant infected by helminthiasis compared with men, similar to what was found by Mekonnen et al (2014) where the more family members the higher the possibility of helminthiasis infection.

\section{a. Personal hygiene nail hygiene}

Based on the analysis of the relationship between nail hygiene and helminthiasis infection, 
a significant relationship was found with $\mathrm{p}=0.009$ and worm prevalence ratio of 2.751, lack of nail hygiene can affect worm infection. Students who have dirty nails affect worm infections twice compared to students who have clean nails. Nail hygiene is an attempt to achieve personal hygiene. Nails should always be cut short at least once a week, the habit of biting nails and inserting fingers into the mouth in children to allow the transmission of worms from the nails of the mouth. This study is in line with the study of ratag (2012) in children in the Sangie island district.

Research conducted by Desti (2015) Wintoko (2014) showed a significant relationship between nail contamination by worm eggs and personal hygiene factors of helminthiasis with a value of $p=0.001$. According to Onggowaluyo (2002) that the transmission of intestinal worms is through hands and dirty finger nails, where the growth of finger nails in one week an average of $0.5-1.5 \mathrm{~mm}$.

Similarly, Kartini (2016) found that students who did not have the habit of washing their hands were 5 times more likely to be infected with worms than students who had the habit of washing their hands. Students who have a habit of washing their hands will allow to reduce the incidence of helminthiasis. The entry of infective eggs through worms dirty hands because their fingers enter the mouth when eating without washing hands (Miftahuz, 2017).

Because infectious eggs / larvae in contaminated land will stick to dirty hands and hidden in long nails so that they enter the human body, clean and manicured nails are a mirror of one's personality. Long and untreated nails will become a place to attach various impurities that contain various microorganisms, including bacteria and worm eggs. The role of family and school is needed in educating children to get used to clean nails regularly. The family tends to be a reactor to health problems that occur in family members and become an actor in determining or dealing with these health problems, for example in this case is to maintain nail hygiene (Friedman, 1998).

\section{b. Personal hygiene use footwear}

Based on the results of the analysis above, it can be seen that there is a significant relationship between the habit of using footwear with helminthiasis infection in elementary school students with a value of $\mathrm{p}=0.004$ with a prevalence ratio value of 3.195 . Similarly, research conducted by Agustina (2000) there is a close relationship between soil contaminated with Ascaris eggs in infants. The same thing with Sarah (2017) states that there is a significant relationship between the habit of using footwear with the incidence of helminthiasis with $\mathrm{p}=$ 0,000. In contrast to research conducted by Rizka (2016) Rizky (2008) where no significant relationship was found between the use of footwear with intestinal helminth infections with a value of $\mathrm{p}=0.133$.

Research conducted by Ching (2010) percentage of soil contamination by STH egg cells in people's home yards is 70\%, as well as conducted by Sumanto (2010), that schoolchildren who live in homes where found in their soil found worm eggs have a risk of infection worms are 10.4 times bigger than living in a house with a yard not contaminated by worm eggs. Therefore, children who are more often playing outdoors and in contact with the ground will be at risk of contaminated with STH eggs in padak who do not use footwear when leaving the house.

Footwear is very effective for blocking worm larvae that enter through the skin, using footwear in the form of sandals or shoes when activities outside the home can reduce skin contact with the ground. Habit of using footwear when doing activities outside the home is a habit that can cause Muthoharoh er, .al. (2015). 


\section{Conclusion}

Based on the results of this study, it can be concluded in the following:

1. Prevalence of Sibolga elementary school students contaminated with Soil Transmitted Helminths is $33.38 \%$.

2. The prevalence of students infected by helminthiasis by sex is $45.45 \%$, out of 44 male students there are 20 infected. The prevalence of female helminthiasis infection is $31.71 \%$, of the 41 female students there are 13 infected.

3. There is a significant relationship between personal hygiene nail hygiene with worm infections in elementary school students with $\mathrm{p}=0.009$.

4. There is a significant relationship between personal hygiene using footwear with the incidence of helminthiasis in students with a value of $\mathrm{p}=0.004$.

Suggestions can be drawn as follow:

1. It is necessary to carry out education about Clean and Healthy Behavior, so that it always applies PHBS in daily life.

2. The need for further research on the relationship of consuming worming with helminthiasis

3. Education needs to be carried out about the dangers, transmission and prevention of Soil Transmitted Helminths infestations through counseling at schools involving UKS students and teachers

4. A septic tank should be made so that the disposal of waste from the toilet does not go directly to the trench, because if there is a flood it will flood around the school environment.

5. The need for the teacher's role in maintaining that during recess, students do not open footwear.

\section{References}

Abera, B., Alem, G., Yimer, M., Herrador, Z. (2013). Epidemiology of soil-transmitted helminths, Schistosoma mansoni and haematocrit values among schoolchildren in Ethiopia. J Infect Dev Ctries. 7(3):253-260.

Centers for Disease Control and Prevention. (2011). Parasites - Soil-transmitted Helminths (STHs). Accessed from http://www.cdc.gov/parasites/sth/ on 29 October 2019.

Dana, D., Mekonnen, Z., Emana, D., Ayana, M., Getachew, M., Workneh, N., et al. (2015). Prevalence and intensity of soil-transmitted helminth infections among pre-school age children in 12 kindergartens in Jimma Town, southwest Ethiopia. Trans $R$ Soc Trop Med Hyg. 109(3):225-227.

Eryani, D. (2015). Hubungan Personal Hygiene dengan Kontaminasi Telur Soil Transmitted Helminths pada Kuku dan Tangan Siswa Sdn 07 Mempawah Hilir Kabupaten Pontianak. Jurnal Mahasiswa Fakultas Kedokteran Untan.

Gandahusada, S., Illahude, D. H., Pribadi, W. (2006). Helminthology in medical parasitology. Jakarta: Balai Penerbit Fakultas Kedokteran Universitas Indonesia.

Garcia, L. S., Bruckner, D. A. (1997). Diagnostic medical parasitology, 3rd Edition. Washington DC: ASM Press; WHO (2019) Soil-Transmitted heliminth infection https://www.who.int/news-room/fact-sheets/detail/soil-transmitted-helminthinfections (Accessed on 30 oct 2019).

Kurniawan, A. (2010). Infeksi Parasit: Dulu dan Masa Kini. Majalaha Kedokteran Indonesia. 60 (11):487-88

Lemeshow, S. et.al (1997). Besar Sampel Dalam Penelitian Kesehatan. Yogyakarta: Gadjah Mada University Press.

Mekonnen, B., Erko, B., Legesse, M. (2014). Prevalence of Intestinal Parasitic Infections and Related Risk Factors among Street Dwellers in Addis Ababa, Ethiopia. J Trop Dis. 2:2. 
Onggowaluyo, J. S. (2002). Parasitologi Medik I (Helmintologi). Jakarta: EGC.

Peraturan Menteri Kesehatan Republik Indonesia Nomor 15 Tahun 2017 Tentang Penanggulangan Cacingan

Rahmat, I., Dachi. (2005). Hubungan Perilaku Anak Sekolah Dasar No.174593 Hataguan Terhadap Infeksi Perut di Kecamatan Palipi Kabupaten Samosir tahun 2005

Rizka Yunmidha Anwar, Nuzulia Irawati, Machdawaty Masria. (2013). “ Hubungan antara Higiene perorangan dengan infeksi cacing usus (Soil Transmitted Helminths) pada siswa SDN 25 dan 28 kelurahan purus, kota padang, Sumatera Barat tahun 2013.

Shumbej, T., Belay, T., Mekonnen, Z., Tefera, T., Zemene, E. (2015). Soil-Transmitted Helminths and Associated Factors among Pre-School Children in Butajira Town, SouthCentral Ethiopia: A Community-Based Cross-Sectional Study. PLoS One: 10 (8).

Sowemimo, O. A., Asaolu, S. O. (2011). Current status of soil-transmitted helminthiasis among pre-school and school-aged children from Ile-Ife, Osun State, Nigeria. J Helminthol; 85:234-238.

Supali, T., Margono, S. S., Abidin, S. A. N. (2008). Nematoda Usus, Didalam: Sutanto, I., et al, Buku Ajar Parasitologi Kedokteran Edisi Keempat. Jakarta: Balai Penerbit Fakultas Kedokteran Universitas Indonesia 